\title{
Discussion on Existing Problems and Solutions on the Last Mile in Rural Logistics of Jilin Province
}

\author{
Jiali SONG*
}

Department of Information Management and Information Systems, College of Management Science and Information Engineering

Jilin University of Finance and Economics

Changchun, China

\author{
Shaohua MA \\ Department of Information Management and Information \\ Systems, College of Management Science and Information \\ Engineering \\ Jilin University of Finance and Economics \\ Changchun, China
}

\begin{abstract}
In order to revitalize the northeast old industrial base and optimize the industrial structure in Jilin province, the development of rural e-commerce has become the main construction content. However, the unimpeded last mile of rural logistics has become the main obstacle to the development of rural e-commerce in Jilin province. According to the present situation of last mile of rural logistics, combining the characteristics of Jilin Province, the paper discusses the root cause of the last mile problem of rural logistics in Jilin province, and puts forward solutions to the last mile of rural logistics in Jilin Province. The ideas in the paper as well as the research achievement have some significance in both theory research or practical use in the coordinative development of rural logistics and regional economy.
\end{abstract}

Keywords-rural e-commerce; rural logistics; last mile; distribution mode

\section{INTRODUCTION}

During the two sessions in 2016, Premier Li Keqiang put forward ten promising industries, rural e-commerce ranked the top of the list. The development of China's rural electric business has begun to take shape. Learned from the national postal management conference in 2018, in 2017, China's postal industry has received more than 10 billion pieces of express delivery in rural areas, the rural market has undoubtedly become a hot spot for business enterprises. At present, the development of rural e-commerce is largely restricted by the last mile of rural logistics. Because rural logistics has characteristics of long Logistics chain and low consumption density, the express delivery cannot enter the village and the household, farmers need to take the express by long distance; it seriously restricts the enthusiasm of rural online shopping. "Logistics ahead of goods flow" has become the key to developing the market. After all, the internet can connect the world by a network line, but the logistics infrastructure needs to be built up gradually. So, in the future, if we can solve the last mile problem perfectly, we can do a good job in the rural ecommerce[1].

Jilin province is a big agricultural province, the development of rural logistics is not only related to the supply of agricultural means of production, the daily demand of farmers', but also to the external circulation of agricultural products and the increase of farmers' income. It is of great

The paper is sponsored by Social science research project in Jilin Provincial Department of Education (No: 2015343). practical significance to develop the rural logistics, speed up the circulation of agricultural products and get through the last mile of agricultural products. It can replace the traditional agriculture with modern farming, and replace the commodity flow with modern logistics. Additionally, the development of rural logistics plays an important role in promoting the appreciation of agricultural products and increasing the income of farmers.

II. INVESTIGATION ON THE CURRENT SITUATION OF RURAL LOGISTICS IN JILIN PROVINCE

Jilin commerce department has issued some notices or opinions on logistics, they play great roles in promoting the development of rural commerce circulation in Jilin province, the scale of rural commerce industry in Jilin province is expanding and developing rapidly. But country logistics develops slowly in Jilin, which has begun to restrict the development of country economy. In May 2018, Jilin Department of Commerce held a conference on the urban and rural distribution, cleared to establish the index system of the urban and rural distribution, proposed to promote open sharing of information platform, enhanced to promote the development of green distribution. So, Jilin Province has a good policy environment for logistics development [2].

At present, according to the flow direction, the types of rural e-commerce logistics in Jilin province can be divided into two categories. The first category can bring the convenience for the farmers; it can bring consumer goods and industrial products to farmers. The second kind is the outflow pattern to help the agricultural products enter the city. The rural logistics is mainly to receive agricultural products, and some products with strong seasonality often have more stringent requirements for logistics distribution. At the same time, there are four types ways of rural logistics in the Jilin province, the first type is Self-run logistics, such as Jingdong logistics, etc. the second type is the third party logistics, such as SF express and Yuantong express. The third type is passenger transport logistics, goods are distributed by the passenger vehicles. The fourth type is Grass-roots logistics; farmers use their own vehicles for distribution. There is not much difference at the dispatching time between the county distribution station and the urban logistics, but the difference is existed in the distributing process that packages are delivered from county 
seat to villages and towns, most of the packages can be delivered to the village government, but they can't be sent to farmers' houses[3].

The author conducted a questionnaire survey on the satisfaction degree of rural electricity providers in the three surname village of Qijia Town, Shuangyang District, Jilin province. The survey found that there was only one logistics express station in an administrative village, a small supermarket owned by a couple can provide CAINIAO logistics business. But this couple is only responsible for notifying people, not responsible for dispatching to the farmers' houses, that is, express packages are delivered to the location of the village government, but the location of the village government is far from the farmers' houses. As we all know, rural residences are scattered and villages are far apart. In the city, the last mile of logistics is actually a mile, but in the countryside, the last mile of logistics is actually a few kilometers in the countryside. There are 13 Tuens in the three surname village. The nearest Tuan is one kilometer away from the village supermarket which is only one logistics express station, but the farthest one is more than six kilometers far away from the logistics express station, therefore, local villagers have serious difficulties in sending and receiving express packages.

\section{DISCUSSION ON THE ROOT CAUSE OF THE LAST MILE PROBLEM OF RURAL LOGISTICS IN JILIN PROVINCE}

\section{A. The contradiction of long logistics chain and low consumption density}

Rural e-commerce is an important way to transform the mode of agricultural development, and it is an important carrier of precise poverty alleviation too. But, the rural ecommerce logistics is facing the dilemma of long logistics chain and low consumption density, because of broad rural areas and dispersed population[4]. The nearest distance is one kilometer from Tuans to the Express Station, the farthest distance is more than 10 kilometers. For farmers, they must walk a long way for getting their express packets. The cost of obtaining express packets is too high in time or in economy, so farmers' enthusiasm for online shopping is not high.

\section{B. The aging problem of rural left behind personnel}

At present, the aging problem of rural left behind personnel in Jilin province is very serious. Rural left behind personnel are generally over 40 years old, and women are the majority. There are 44 households in the three surname village of Qijia Town, Shuangyang District, Jilin province, there are 10 households whose average age is over 70 years old, there are 13 households whose average age is over 60 years old, there are 12 households whose average age is over 50 years old, there are 7 households whose members are women and children, there are only 2 households that is a combination of parents and children, and one is the owner of that express station. The elderly can't use computers and mobile phones, they aren't the main groups of rural electricity consumers, but they are beneficiaries of rural logistics, because they usually receive express packets from their children who are working outside. But because the rural express delivery can't reach home, so the elderly left behind in rural areas enjoy the convenience of rural e-commerce, but they are also be troubled by walking long distance for getting their packets.

The aging of rural left behind personnel is becoming more and more serious. And the development of rural logistics also needs young and middle-aged labor force to work, so we say that the aging of rural population is extremely unfavorable to the development of rural logistics[5].

\section{Lacking of two-way logistics system}

Rural logistics provides services for rural residents, it is a general term of all related logistics activities by packaging, processing, warehousing, transporting, loading and unloading, and so on. Rural logistics is a two-way circulation system. It is necessary to solve the problem of how to import agricultural means of productions and daily industrial products to the countryside and how to export agricultural products from the countryside. The business model platform of rural e-commerce is very complex, besides linking businesses who can provide services to farmers, it also links farmers. So the two-way logistics distribution capabilities are necessary, but rural logistics in Jilin province is lacking this two-way capability. Therefore, Jilin Province should vigorously build a two-way logistics system, improve the utilization rate of existing logistics infrastructure equipment, and complete the effective docking with urban logistics.

\section{Lacking perfect logistics information platform}

Informatization is the inevitable trend of modern logistics development. Because Jilin Province did not pay enough attention to the rural logistics in the past, and the enthusiasm of participating enterprises was not high, the overall quality of the rural logistics is not high. At present, the construction of rural logistics lags behind seriously. Information can't be shared among logistics enterprises, and information can't be shared between logistics enterprises and farmers, production enterprises and circulation enterprises. Jilin province has low ability to enhance the operation level of rural logistics through information technology.

\section{WAYS AND MEANS TO SOLVE PROBLEMS}

\section{A. Developing Postal Logistics to Promote the Development o f rural logistics}

We can make full use of postal network. From the 2008 National Postal Management Conference, we learned that in 2017, The development environment of China's postal industry has been continuously optimized, the structural reform on the supply side has been gradually deepened, and the postal industry has made remarkable achievements in serving the people's livelihood. In the first half of 2018, Jilin Province completed 97.03.71 million pieces of postal express service, this is an increase of $21.43 \%$ over than the same period of the last year, and the cumulative business income reached 1.682 billion yuan. Postal industry has the longest, the most complete and the widest logistics distribution network, therefore, Jilin Province should make full use of postal 
network resources when promoting e-commerce into rural areas, to solve the last kilometer problem of the rural logistics.

\section{B. Developing the infrastructure of rural logistics}

Infrastructure construction is the foundation and the key of developing modern logistics industry. The concrete realization of each logistics function, such as packaging, circulation and processing, transportation, handling, information processing and so on, depends on the construction of logistics infrastructure and the input of logistics technology.

Jilin Province should increase the construction of rural highways, so that rural highway can access every village, open up the highway microcirculation to solve the highway "last kilometer" problem. To resolve the contradictions of rural logistics, logistics network can be built by the original supplying and marketing cooperatives and modern logistics enterprises. Remote natural villages can set up a logistics point in the townships and deliver the products on a regular basis. Modern enterprises should be introduced into the countryside to speed up the development of modern agriculture, for example, cold chain enterprises can settle down in towns with good conditions. Advanced enterprises drive the development of agriculture, and enable farmers to get rid of poverty and become rich.

\section{Increasing government support to solve the last kilometer problem in rural areas}

It is impossible to solve the "last mile" problem of rural logistics and to make agricultural products from the field to the dining table conveniently by a single enterprise or individual, government intervention and policy support are needed here. The government can build a supply chain service system for agricultural products, build a smart logistics platform, and promote three levels of coordination among counties, townships and villages. Jilin province should seize the opportunity of the development of "Internet + circulation", strive to break through the lags of information infrastructure and cold chain transportation, and build intelligent logistics system as soon as possible.

In the future, Jilin province should strengthen the construction and management of green intelligent agricultural products supply chain, strengthen the research and development core technology of green intelligent agricultural supply chain, make full use of the big data and artificial intelligence in logistics management, try its best to build a complete and open supply chain integrated service system for warehouse, distribution, customers and After-sale service.

\section{Developing the third party logistics and public distribution mode vigorously}

Logistics operation and distribution mode are the core elements which can determine the efficiency of rural logistics operation. With the in-depth development of rural logistics, the main body operation of rural logistics in Jilin Province presents a diversified, multi-level development trend. In addition to postal enterprises, the original transport enterprises and agricultural enterprises, small transportation enterprises and individual transporters who specialize in agricultural production and life are also rising rapidly. Public distribution centers should pay attention to the training, incubation, public innovation and logistics delivery of rural e-commerce. And public distribution centers should promote resource integration and do well in the unified distribution of e-commerce products. logistics enterprises carry out centralized distribution in urban areas, towns and administrative villages, so regional goods can be sent from regional logistics centers to all parts of the country. Distribution in villages and towns and administrative villages adopts the mode of fixed-point, fixed-time, fixed-line, uniform freight rate, uniform service fee, uniform distribution, uniform government subsidy standards, logistics transportation regularly delivers and receives the agricultural products to the regional logistics center, and distributes them according to the customer's address.

There are many problems in the rural logistics, such as the inconvenience of traffic, the inconvenience of road conditions, the lack of information such as door signs, different accents, and so on. To solve these problems, we need to use "sharing" thinking. That is, on-line "county wisdom logistics" network system Seamless connects with e-commerce and third-party logistics express, mobilization of idle people and cars in villages and towns and administrative villages, and mobilization of township supply and marketing cooperatives, husband-and-wife shops, farmhouse recreations and small shops that have cars and people and are familiar with local traffic. Off-line, we should fully mobilize idle people and vehicles in towns and administrative villages. These people have their own cars and are familiar with local transportation, such as those who own village and township supply and marketing cooperatives, husband and wife stores, farmhouse resorts, snack shops in the countryside. Let these people undertake third party orders to meet the logistics needs of the rural masses.

\section{E. Building rural intelligent logistics platform}

We need to build a rural intelligent logistics network platform to boost the unified distribution of rural e-commerce logistics, construct county-level logistics public distribution center, build rural terminal logistics line sharing system, and share data with provincial and municipal logistics management system[6]. The platform can integrate all kinds of social logistics resources in the region to build a county-level rural logistics distribution center with data-driven and social coordination, and it integrates the supply chain system through the third-party logistics enterprises, and integrates the county and rural three-level logistics network resources to form a shared logistics platform. The platform can gradually improve the logistics distribution system and operation mechanism, carry out unified management and operation according to unified standards, develop the business of agricultural products' processing and warehousing and distribution, finally realize the effective connection between regional rural logistics service network and trunk logistics network.

\section{CONCLUSION}

As the very important link between production and consumption, urban and rural, industrial and agriculture, the construction and development of rural logistics has great 
significance for promoting the sustainable development of regional economic. Logistics services to the countryside can't be achieved only by shouting slogans, but also need to be down-to-earth construction. Although the "last mile" logistics problem makes the development of rural e-commerce in Jilin Province difficult, but we believe that we can break this bottleneck through the strong support from the government and the joint efforts of logistics enterprises. Jilin Province can eventually built a network perfection, urban-rural convergence, model advanced, scientific management, efficient operation, green and open urban-rural distribution system, and comprehensive logistics network covering and the booming logistics industry is the corner stone of the rural economic development and the modern agricultural growth.

\section{REFERENCES}

[1] Xu Yuan, "Research on the 'last mile' information system of rural logistics," SCIENCE \& TECHNOLOGY INFORMATION. China, vol. 14, pp. 20-21, April 2016. (In Chinese)

[2] He Juan, "Research on the 'last mile' construction of rural e-commerce logistics,” MODERN BUSINESS. China, vol. 8, pp. 39-40, April 2016. (In Chinese)

[3] Miao Xiaofeng, "Discussion on Existing Problems and Countermeasures of 'Last Mile’ of Rural Electronic Business Logistics,” SHANXI RTVU JOURNAL. China, vol. 19, pp. 90-92, June 2017. (In Chinese)

[4] Li Foshang, Song Shaozhong, "Research on the development path of rural e-commerce logistics in Jilin Province," South Agricultural Machinery. China, vol. 48, pp. 12-12, June 2017. (In Chinese)

[5] Xie Jiagui, Zhang Tingting, Chen Hongxu, "Part-time Courier: An Effective Solution to Last-mile Problem of Rural Express Delivery Industry,” Logistics technology. China, vol. 35, pp. 33-35, August 2016. (In Chinese)

[6] Zhou Jianjun, “The current situation and trend of China's agricultural ecommerce under the environment of 'Internet +',"'Agricultural Outlook. China, vol. 6, pp. 81-84, June 2016. (In Chinese) 